\title{
Correction to: Consensus on the secondary prevention of primary liver cancer
}

\author{
Yuemin $\mathrm{Nan}^{1}$ (D) Xiaoyuan $\mathrm{Xu}^{2} \cdot$ Yanhang $\mathrm{Gao}^{3} \cdot$ Rongqi Wang $^{1} \cdot$ Wengang $\mathrm{Li}^{4} \cdot \mathrm{Ming} \mathrm{Yang}^{5} \cdot$ Lingdi Liu $^{1}$. \\ Zhongping Duan ${ }^{6} \cdot$ Jidong Jia $^{7} \cdot$ Lai Wei $^{8} \cdot$ Hui Zhuang ${ }^{9} \cdot$ Chinese Society of Hepatology, Chinese Medical \\ Association
}

Received: 11 December 2021 / Accepted: 11 December 2021 / Published online: 12 January 2022

(c) The Author(s) 2022

\section{Correction to: Hepatology International (2021) 15:1289-1300 https://doi.org/10.1007/s12072-021-10259-7}

The article [Consensus on the secondary prevention of primary liver cancer], written by [Yuemin Nan, Xiaoyuan $\mathrm{Xu}$, Yanhang Gao, Rongqi Wang, Wengang Li, Ming Yang, Lingdi Liu,Zhongping Duan, Jidong Jia, Lai Wei, Hui Zhuang, Chinese Society of Hepatology, Chinese Medical Association], was originally published Online First without Open Access. After publication in volume [15], issue [6], page [1289-1300] the author decided to opt for Open

The original article can be found online at https://doi.org/10.1007/ s12072-021-10259-7.

Yuemin Nan

nanyuemin@hebmu.edu.cn

Xiaoyuan Xu

xiaoyuanxu@bjmu.edu.cn

Yanhang Gao

yanhang@mail.jlu.edu.cn

Rongqi Wang

wangrongqiw@163.com

Wengang Li

doctor302@163.com

Ming Yang

ymicecream@163.com

Lingdi Liu

liulingdi2016@163.com

Zhongping Duan

duan2517@163.com

Jidong Jia

jiamd@263.net

Lai Wei

weilai@pkuph.edu.cn

Hui Zhuang

zhuangbmu@126.com
Choice and to make the article an Open Access publication. Therefore, the copyright of the article has been changed to (C) [The Author(s)] [2021] and the article is forthwith distributed under the terms of the Creative Commons Attribution [This article is licensed under a Creative Commons Attribution 4.0 International License, which permits use, sharing, adaptation, distribution and reproduction in any medium or format, as long as you give appropriate credit to the original author(s) and the source, provide a link to the Creative Commons licence, and indicate if changes were 
made. The images or other third party material in this article are included in the article's Creative Commons licence, unless indicated otherwise in a credit line to the material. If material is not included in the article's Creative Commons licence and your intended use is not permitted by statutory regulation or exceeds the permitted use, you will need to obtain permission directly from the copyright holder. To view a copy of this licence, visit http://creativecommons. org/licenses/by/4.0/.

Open Access This article is licensed under a Creative Commons Attribution 4.0 International License, which permits use, sharing, adaptation, distribution and reproduction in any medium or format, as long as you give appropriate credit to the original author(s) and the source, provide a link to the Creative Commons licence, and indicate if changes were made. The images or other third party material in this article are included in the article's Creative Commons licence, unless indicated otherwise in a credit line to the material. If material is not included in the article's Creative Commons licence and your intended use is not permitted by statutory regulation or exceeds the permitted use, you will need to obtain permission directly from the copyright holder. To view a copy of this licence, visit http://creativecommons.org/licenses/by/4.0/.

Publisher's Note Springer Nature remains neutral with regard to jurisdictional claims in published maps and institutional affiliations. 